\title{
How Can the North Polar Region Be Crossed?: Discussion
}

Author(s): Leopold M'Clintock, George Nares, E. Inglefield, Allen Young, Captain Wiggins, Captain Wharton, Fridtjof Nansen, George H. Richards and Joseph D. Hooker

Source: The Geographical Journal, Vol. 1, No. 1 (Jan., 1893), pp. 22-32

Published by: geographicalj

Stable URL: http://www.jstor.org/stable/1774199

Accessed: 25-06-2016 05:11 UTC

Your use of the JSTOR archive indicates your acceptance of the Terms \& Conditions of Use, available at

http://about.jstor.org/terms

JSTOR is a not-for-profit service that helps scholars, researchers, and students discover, use, and build upon a wide range of content in a trusted digital archive. We use information technology and tools to increase productivity and facilitate new forms of scholarship. For more information about JSTOR, please contact support@jstor.org.

The Royal Geographical Society (with the Institute of British Geographers), Wiley are collaborating with JSTOR to digitize, preserve and extend access to The Geographical Journal 
the open air, skin or canvas suits to put outside the woollen clothes are necessiry to protect one against the biting wind and the snowdrift. To heat our saloon there will certainly not be much wanted even during the severest cold. A few paraffin lamps or a small paraffin stove will certainly be sufficient. There will of course also be care taken to get good ventilation. We thus run no risk, I think, of suffering from the want of heat. With the light it is, however, worse. Almost no organism can exist without that, and therefore various illnesses occur during the long Arctic nights. This it would seem difficult to avoid in regions where the darkness lasts six months. I believe, however, that we shall be able to overcome this difficulty also by help of the wonderful electric light. We shall have a dynamo for producing electricity. Many will perhaps ask how we shall get the necessary power to make it work. This cannot, however, be difficult. On one hand we have the wind. The meteorologists are certainly of opinion that this will not, as a rule, be very strong in the cold over the Polar Sea; but a little we must find there also, and if the sails of our windmill are made sufficiently big, we do not want much to turn them. But eren when there is no wind at all we will be able to produce power. We are twelve men, strong, and well-picked, as I hope, and when a capstan is arranged on deck we will be able to do work similar to that which a horse does in its horse-mill on land. In this capstan four men take their turn at a time; thus we will obtain good and regular exercise-somewhat monotonous perhaps-and will at the same time be useful by producing electricity, so that we can have an electric arc-lamp burning eight hours a day. Everybody will understand what a blessing that must be when one is surrounded by constant darkness. When the sun begins to sink to disappear behind the horizon in the south for the last time we begin to walk in a ring in the darkness on the deck of our ship, in order to produce a new sun. In this way we will slowly move forward. I hope that you, ladies and gentlemen, will sometimes send us a kind thought while we go round in our mill there far north in the solemn silence of the long polar night.

Admiral Sir Leopold M'Chrstock: I think I may say this is the most adventurous programme ever brought under the notice of the Royal Geographical Society. We bave here a true Viking, a descendant of those hardy Norsemen who used to pay this country such frequent and such unwelcome visits. One cannot but admire Dr. Nansen's splendid enthusiasm. He has adduced some very striking proofs as to the current to which he intends to trust himself and his companions; he has shown us that the current is proved to extend to the north-west from Barents Strait, at least to lat. $77^{\circ}$; has reminded us of the Dutch fleet frozen in on this side the Pole in lat. $78^{\circ}-80^{\circ}$ between Spitzbergen and Greenland, and which drifted south, sometimes in sight of Greenland, sometimes in sight of Iceland, until the last one was crushed somewhere near Cape Farewell. Thus we have a north-west current running in, and a south-west current running out, and the unknown intervening space, the so-called Polar Basin, is 1500 geographical miles; and this is just 
the space which has so many attractions for Dr. Nansen, that he proposes to drift across it. I wish to say only a few words, and those with reference to the minor currents, with which I am personally acquainted or have had some experience. We find on the American Islands an enormous pressure of Polar ice, very different in character from anything further soutb, pressing in from the west and choking up all the channels between them, up to $83^{\circ} \mathrm{N}$.; but though this heavy ice bars the channels, it does not stop the flow of the current underneath, which runs into Baffin's Bay and so gets into the Atlantic Ocean; and this may have some bearing upon Dr. Nansen's current. I sincerely trust Dr. Nansen will succeed in getting into mid-current north of the New Siberian Islands, because then he will be in less danger of being impeded by all these American Islands on the one hand, and Spitzbergen and its neighbouring islands on the other, whereon are cast great quantities of Asiatic timber-trees brought down by the Siberian rivers; so I suppose as Siberian driftwood can be carried, Dr. Nansen's ship could be carried, and I hope he will come straight through. But all these dangers are very small as compared with the dangers of the ice to which he proposes to trust himself. This great Polar ice is so much heavier than that which is met with in Straits, or in Baffin's Bay, which discharge their ice annually into the Atlantic. De Long was beset in one year's ice about 6 feet thick; nearly two years later with the same ice, which had grown very much thicker round the ship, the Jeannette was crushed. At that time the thaw had not commenced, and the ice was still firmly frozen to her sides, so that for the ship to have been pressed up, would have been an exceedingly difficult operation. The ice imprisoned in this Polar basin for some years grows thicker from year to year. Dr. Scoresby tells us that the great ice fieids in lat. $80^{\circ}$ average in thickness $10-24$ feet, and where hummocks occur it is often up to 40 feet or even 50 feet. By the crushing of the floes these great masses are pressed against each other, and overlaying, get frozen together, so that there may be almost any thickness of ice. Dr. Nansen has very fully described his ship to us, and I think she should accomplish all that any vessel could do. He attaches much importance to the wedge shape of the vessel under water, where the ice pressure will tend to lift her up. My own last Arctic vessel the Fox was precisely of that build: and the rotten ice, not more than a foot above the surface of the water in summer-time, would crush against her sides, pass under her, and still crushing against the wedge-shaped bcttom, tend to lift her up, and so she frequently escaped from being crushed. I am glad to say she was never squeezed by the ice during the winter months, when the ice was of quite a different character-more like rock frozen fast to the ship's side. The possibility of sliding up on to the ice is then, I think, very remote. Dr. Nansen has alluded to his boats, 29 feet long, as being convenient for the reception of his men on the ice. I would prefer much more portable boats, such as could be readily and quickly removed from any position of danger ; for these floes are so frequently rushing against each other and crusing together, that what is safe at one moment may half an hour afterwards be extremely unsafe; it is better, therefore, to have portable boats, and I would trust to snow huts built upon the ice, for shelter in the extreme cold. While I wish Dr. Nansen complete and speedy success, it will be a great relief to his many friends in England when he returns; and more particularly to those who have had some experience of the dangers at all times inseparable from ice navigation, even in regions not quite so far north.

Admiral Sir George Nares: It is a delicate duty to criticise the details of any voyage fully determined on, and is especially so in regard to an exploring voyage to be undertaken by another nation. But as Dr. Nansen has submitted his programme to this Society, the Arctic members are bound to give you 
their opinion. In anything I say Dr. Nansen may be sure that it is said in a friendly spirit, with the greatest admiration of his plucky proposal, and his powers of endurance and readiness of resource under extreme circumstances, as displayed in the past. I would also say at once that, whatever the result of the voyage may be, we are satisfied that he will give us on his return a good account of such parts of the Polar area as he may reach. The adopted Arctic axioms for successfully navigating an icy region are, that it is absolutely necessary to keep close to a coastline, and that the farther we advance from civilisation the more desirable is it to insure a reasonably safe line of retreat. Totally disregarding these, the ruling principle of the voyage is that the vessel-on which, if the voyage is any way successful, the sole future hope of the party will depend-is to be pushed deliberately into the pack-ice. Thus her commander-in lieu of retaining any power over her future movements-will be forced to submit to be drifted helplessly about, in agreement with the natural movements of the ice in which he is imprisoned. Supposing the ocean currents are as stated, the time calculated as necessary to drift with the pack across the Polar area is several years, during which time, unless new lands are met with, the ice near the vessel will certainly never be quiet, and the vessel herself never free from danger of being crushed by ice pressure. To guard against this the vessel is said to be unusaally strong, and of a special form to enable her to rise when the ice presses against her sides. This idea is no novelty whatever; but when once frozen into the Polar pack the form of the vessel goes for nothing. She is hermetically sealed to, and forms a part of the ice-block surrounding her. The form of the ship is for all practical purposes the form of the block of ice in which she is frozen. This is a matter of the first importance, for there is no record of a vessel frozen into the Polar pack having been disconnected from the ice, and so rendered capable of rising under pressure as a separate body detached from the ice-block,"even in the height of summer. In the event of the destruction of the vessel, the boats-necessarily fully stored, not only for retreat, but for continuing the voyage-are to be available. This is well in theory, but extremely difficult to arrange for in practice. Preparation to abandon the vessel is the one thing that gives us the most anxiety. To place boats, \&c., on the ice packed ready for use involves the danger of being separated from them by a movement of the ice, or of losing them altogether should a sudden opening occur. If we merely have everything handy for heaving over the side, the emergency may be so sudden that we have not time to save anything. So the only feasible plan is to arrange for sledges, boats, stores, \&c., to be as accessible as possible, and, in the words of De Long, "Stick to the ship as long as she will stick to us, and when she is ready to leave us try to be a little readier to leave her." As to the direction of drift of the Polar ice we all agree with Dr. Nansen as to the southerly movement of the water between Spitzbergen and Greenland. We may, therefore, accept the homeward carrying current on which he proposes finally to depend. He has, in my opinion, overstated its depth; but that does not in the least affect his main deductions. We may also infer that a similar movement of the water, with a reducing velocity, will be met with north and north-east of Spitzbergen for a distance of 500 or 600 * miles-that is, to about as far as the Pole itself. Of the other water movements, there is the current from the Atlantic towards the Barents Sea. This is proved by the drift of Weyprecht and Payer to be so slight that it was completely overpowered by the wind pressure. The wind it was that carried them to FranzJosef Land. Again, the reported Bering Strait current has so slight an effect along the Siberian coast that De Long-in the Jeannette, and while retreating south over the ice-was similarly drifted about by the prevailing winds, and by them 
only. De Long frequently refers to the fact, and his final record left on the ice after the vessel disappeared states-"As the prevailing winds are from the southeast, this ancient ice moves slowly along to the north-west. There are no currents which are not caused by the wind prevailing at the time." There remains for consideration the effect of the fresh water discharge from the rivers. This, doubtless, exerts an influence some distance seaward, but only during the summer and autumn; and even then the largest cannot cause any appreciable movement in the ice farther than about 200 miles from the mouth. Beyond this distance seaward, the wind-drift must overpower that produced by any other means. As to the probable direction of the drift, the Fram, starting from near the mouth of the Lena river, may expect to meet the main pack no farther north than about lat. $76^{\circ} 30^{\prime}$. I doubt her getting farther north before she is beset; but, taking an extreme case, and giving her 60 miles more, she will then only be in the same latitude as 'Cape Chelyuskin-730 miles from the Pole, and about 600 miles from my supposed limit of the effective homeward carrying ocean current. After a close study of all the information we possess, I think the wind will be more likely to drift her towards the west than towards the east. With an ice-encumbered sea north of her, and more open water or newly-made ice to the southward, the chances are small for a northerly drift, at all events, at first; and, afterwards, I know of no natural forces that will carry the vessel in any reasonable time much farther from the Siberian coast than the Jeannette was carried, and, during the whole of this time, unless protected by newly-discovered lands, she will be to all intents and purposes immovably sealed up in the pack and exposed to its well-known dangers. There is no doubt that there is an ocean connection across the area proposed to be explored. In conclusion, I join with Dr. Nansen in considering that the principal aim of all such voyages is to explore the unknown Polar regions, not to reach exactly that mathematical point in which the axis of our globe has its northern termination, and I offer him my hearty wishes for a successful voyage.

Admiral Sir E. INGLefield : After the remarks made by the distinguished Arctic navigators who have just spoken there is little for me to say. I think I can give Dr. Nansen a word of encouragement by telling him that on my second voyage I walked up one shore of Wellington Channel to meet Sir Edward Belcher, and one evening we were lucky in finding a pine tree one foot in diameter, and about-as far as I can remember-15 to 16 feet long, with the bark upon it, and very little bruised. We know it can have come from no other part of the world but Siberia. I may add that a portion of the bark of that tree was brought home, and the naturalist with a microscope discovered seeds and matter upon it which assured him it had not been more than a few months in the water. 'This was on the western shore of Wellington Channel, which, as everyone knows, runs into Baffin's Bay. I made three voyages to Beachy Islands, \&c., the first in a little yacht of 150 tons, the others in Government vessels of 800 tons; and I may say that if I had to go again I would prefer the 150-ton vessel.

Sir Allex Young: I am called upon unexpectedly to say a few words, and really after what we have heard from Sir Leopold M'Clintock and Sir George Nares there is little left to say. I believe there can be no doubt that these relics from the Jeannette were genuine, and must have drifted on the floe on to which they were thrown when the ship was abandoned, and could have come to the Greenland coast in the time, by no other way but across the Pole, or nearly so. Dr. Nansen assumes that the blank space around the axis of the earth to be a pool of water or ice; I think the great danger to contend with will be the land in nearly every direction near the Pole. Most previous navigators seem to have continued seeing land again and again further and further north. These Jeannette relics may have 
drifted through narrow channels, and thus finally arrived at their destination; and, I think it would be an extremely dangerous thing for the ship to drift through them, where she might impinge upon the land and be kept for years. It is only to be hoped that Dr. Nansen will be equipped with such gear as to enable him in case of disaster to retreat to open water; and I quite agree with Sir Leopold M'Clintock that these large boats will not be available for that purpose. With reference to land about the Pole I may mention that when I was at Upernavik on the west coast of Greenland, the Governor had a reindeer skin which had been branded with a mark like those which the Siberians use for their tame reindeer, and tame reindeers are unknown in Greenland ; therefore this reindeer must have come from the coast of Siberia, either round the north point of Greenland or across the inland ice. It must have come across islands stretching from some point in Siberia; and this goes to prove that there are islands on the way. We know, of course, that the Gulf Stream washes the shores of Norway, and also Novaya Zemlya, and turns again to the westward, as is evidenced by the fact that glass balls used by the Norwegian fishing-boats are found on the west coast of frreenland. It reaches, perhaps, to Franz Josef Land; but further we know nothing save from the relics of the Jeannette, which afford strong proof of the existence of such a current. Dr. Nansen says that the Jeannette was not a strong ship. I am glad to say that I found the Pandora, as she then was named, an extremely strong ship. We had some severe nips, and yet the ice did not come through her, although on one occasion some of her beams were broken. In my opinion she was too strong; for had she not been so strong she would have been crushed in the first winter, and those heroic men who have gone and whose loss we all deplore, would have been still with us. I do not think the form of the ship is any great point; for when a ship is fairly nipped the question is if there is any swell or movement of the ice to lift the ship. If there is no swell, the ice must go through her whatever she is made of. The great danger to the Fram is in case she is impinged against some land and there remains. I hope Dr. Nansen will start from the west of the New Siberian Islands, because island after island were discovered by the Jeannette, and if he commences his drift from the north or north-west of these islands, he will start on a fairer basis than from the eastward. I only wish Dr. Nansen a most happy voyage, and that he may get through, and soon be with us again.

Captain Wiggiss: It is so late that I cannot say all I should like to say upon this most interesting question of Dr. Nansen and his glorious scheme. It gives me great pleasure to meet Dr. Nansen for the first time. I have never had the pleasure of shaking hands with him yet, but I shall not allow him to leave this platform until I do. I should have liked to have seen the track shown on the chart; I understood he was to go by Bering Strait and to the north of the New Siberian Islands in the track of the Jeannette. With such a route I could not see my way clear to say one word in favour of Dr. Nansen's adventurous voyage. I have heard since from his own lips that he rather contemplates going by waters nearer home, and what is of more importance, taking up what I recommended in 1876, the route inside Novaya Zemlya through to the Kara Sea, thus taking the full swing of the Gulf Stream, which we know flows in there with great force and regularity; and it must go somewhere. To those seas I have been seven or eight voyages, and never yet returned on account of ice. The thermometer there shows us $45^{\circ}$ to $50^{\circ}$ Fahr. in the water passing through the Straits. I cannot to-night say one-half of what I should like to say, but if I could have the honour of doing what I have never done in this room-reading a paper-I cotid, in an hour and a half, make it very clear that it might not be impossible to take the ice and cross the regions of the Pole, if not the Pole itself. As I pointed out in 1876, I found open water all the 
way to Dickson's Harbour in 1874-75, and I believed the best course to the Pole would be through the Kara Sea, not further east than the Chelyuskin promontory, i.e., $100^{\circ}$ long. The only risk will be, as Sir Allen Young pointed out, the question of land. No doubt land will be found distributed about the Pole more or less, even shoals. It has been found before, not only by the Jeannette, but by the Austrian expedition in the Tegetthoff, which I had the honour of searching for in 1874 in the Diana; and when I found them at Hammerfest they acknowledged I was quite right in advising them to go inside the Kara Sea. I felt certain the best currents were there; and along the Siberian shore there are always natives who could help. De Long did not lose his life for want of natives, but by exposure in the boats; he perished at the mouth of the Lena by the storms; the two men who escaped easily found the natives. I would advise Dr. Nansen not to take the New Siberian Islands, as they are most treacherous, low, sandy, muddy, horrible places, and on account of the Lena, there is broken water all the year round, and that is bad for sledging. Baron Wrangel found open water there in midwinter. With regard to going on the top of the ice I am at one with Dr. Nansen, the only difference being that I believe in small things. I did my first voyages in the Diana of 120 tons, and was crushed upon the top of the ice, and in my ignorance, in 1874, rammed the ice in splendid style, and had some hair-breadth escapes, having entered the Kara Sea too early in June and July. I should recommend instead of so large a vessel a smaller one, or to take a small one with him, as with a small vessel you can do much more on the top of ice than with a large one. A vessel may rise when it is squeezed by the ice, though the chances are much against it. The Tegetthoff rose until her keel was on top of the ice, like the model of a steamer on a table. I should recommend, if there is room, not to wait for a squeeze, but to run the vessel as far on top of the ice as possible. A small vessel of 20 or 30 tons might be easily hove round a headland like a huge sledge on the top of ice-floes. If I were going now I would take three small vessels-or at any rate two-as being better than one big one. I should recommend Dr. Nansen to go through the Kara Sea, and on the 100th parallel the current would be always with you. I wish him God speed.

Captain Wharton, R.s. : At this late hour I will say a very few words. As I have not Arctic experience I suppose I am called upon as the professional guardian of the currents of the world, and all I can say on that point is that so far as Dr. Nansen has spoken about the currents that are known he is correct. He speaks of articles thrown upon the coast of Greenland: that is according to fact. As regards the ice I cannot tell you anything. I believe, after close investigation into known currents, that Dr. Nansen is quite justified in supposing there is a drift from the New Siberian Islands, or that side to Greenland, but as to its direction or speed that, as he has told us, is pure speculation. He is not going into this matter with his eyes shut. He has argued the question out very closely, and given us an admirable paper. People sometimes ask, What is the use of Arctic exploration? Amongst other things I think it may be said that its use is to foster enterprise and bring gallant men to the front. To-night we have an excellent example of that in Dr. Nansen. I can only say to him, "God speed."

The President : It is very late, and although there are still many eminent Arctic travellers present-Admiral Ommanney, Dr. Rae, and others-I think it will not be your wish to hear any further speakers. I ought to mention, however, that I have received a long letter-too long to read-from Sir George Richards on this subject; and, although admiring Dr. Nansen, be is obliged to speak unfavourably of his project, adding that anyone speaking with authority ought to speak out when so much is at stake. Dr. Nansen will perhaps like to answer in a few words, and then the meeting will close. 
Dr. NANSEN : I use this opportunity to express my most hearty thanks to those eminent Arctic men who have given their opinions and criticism upon my scheme to-night. I must, at the same time, say that I could get no better encouragement for my expedition, because their criticism has not been able to convince me that I am wrong in my opinion about the currents or about the expedition. Sir Leopold McClintock, Sir George Nares, and Sir Allen Young say that it would be impossible for the ship to be lifted during the winter, but that it would be frozen in. Well, I will not detain you by giving you my opinions about that, but will only say that we have, as Captain Wiggins mentioned, one very good instance of a ship being lifted during the winter, viz., the Tegetthoff. She was lifted so high that her keel was above the surface of the ice. That, in my opinion, is enough to prove that the vessel can be lifted even in the winter, and that she may drift in the ice for years without being crushed, if she is only strong enough to withstand the pressure necessary to lift her. The Tegetthoff, indeed, was safe when she was deserted because of the fear that she would not move again. It is also maintained that my boats are too heavy; but I had not the time to read all about the equipment of the expedition, or I could have told you that I am going to carry about ten boats of various sizes, and some of these will be exceedingly light. Of course, the heavy boats are only to be placed on the ice for living in, because the small boats are too small to live in comfortably. Sir George Nares said he thought an Arctic expedition should always secure a line of retreat. I am of the opposite opinion. During my expedition to Greenland I proved that it is quite possible to accomplish something when you have no retreat, for we then burned our ships behind us, and, in spite of it, got across Greenland; and I hope to be as successful when we break the bridge behind us this time, if no other circumstances intervene to prevent us from getting through. Sir George also referred to the great risk run by the boats through floating ice. I refer you to the experience of the Hansa Expedition. They kept their boats for a whole winter drifting south along the east coast of Greenland, and when the hut they built of their coal was broken by the breaking up of the ice they took refuge in their boats, sleeping on board during the nights for safety; so I do not think it impossible to keep boats safe on the ice if you only take proper care of them. This was also my experience in drifting along the East Coast, and we had some bad experiences. The worst thing in that respect is, in my opinion, not the ice, but the surf, and we run no risk of that in the Arctic regions when surrounded by ice. As to the winds :-I mentioned in my paper, that according to my opirion the winds will not be against us, but in favour of my scheme; in fact, the wind is the principal cause of the currents, and if we can say with certainty that a definite current is constantly running in a distinct direction, we may as a rule conclude that the average direction of the winds go the same way; but I think we need not go further into this question at present, as we actually know very little of the winds in the unknown Arctic regions; the only experiences of much importance in this respect are those of the Tegetthoff and the Jeannette, and they do not seem to speak in my disfavour. In my opinion Sir George Nares was not able to prove that my arguments for the existence of such a current as I assume were wrong. Sir Edward Inglefield was kind enough to mention the finding of drift-wood from Siberia on the shores of Wellington Channel coming from the north. So long as that and similar evidences are undeniable facts, I think it shows that there must be ice constantly floating across, as the drift-wood cannot dive under the ice. As regards the ice conditions, at the New Siberian Islands I have received some information from Baron von Toll, who has spent two years there, and I regret time will not allow me to give you details; but the sense of it is that the sea generally is open to the west of the New Siberian Islands during August. How far north that prevails nobody 
knows, but in my opinion it cannot be a short distance, as the River Lena sends out a quantity of fresh warm water during the summer into the shallow Polar Sea, and produces a current running north. I thank Sir Edward most heartily for the proof of the current he has given. I quite agree with Sir Allen Young that one of the greatest risks is to meet land, and as I said in my paper it is very likely that we will meet land further north. The Tegetthoff expedition was stopped by land, but I do not think that such a thing is likely to happen very often; if there is land in the north it is, of ccurse, quite possible that we may drift against it, but the probability is that the current shall carry us past it, as it does with most part of the ice; and this will become the more certain if we get into the heart of the current; but if we are stopped we have nothing to do but to leave the ship and travel on with the current. If we only keep with the current and do not go against it I do not think it impossible to reach open water and get home in that way. I must thank Captain Wiggins for his most interesting remarks, but I must say I never thought of taking the Jeannette route; my idea was at first to go through Bering Strait and along the Siberian coast to the New Siberian Islands, and thence go north, as I thought that it would be easier to reach these Islands that way than through the Kara Sea and past Cape Chelyuskin. By examining the question more closely, I have come to the conclusion that the advantage of this first route is not quite certain; and then, of course, I prefer the shorter one through the Kara Sea. I quite agree with Captain Wiggins that the best route to follow is to keep as much to the coast as possible; therefore my ship was made to draw as little water as possible in order to be able to travel inside the ice along that shallow coast. Captain Wiggins recommended a small ship; I think a ship 29 feet long ought to be small enough, and I have two such small ships. I will conclude by thanking the Geographical Society and the English Arctic explorers for the cordial way in which they have received me and my scheme.

T'he President : You have listened to Dr. Nansen, you have admired his foresight in anticipating and providing against difficulties, his resource, his ingenuity in details, his courage and his enthusiasm. You have heard the views of some of our greatest Arctic authorities. The views of some others which there has not been time to read, including those of Sir Joseph Hooker, whose experience was gained in the Antarctic regions, and as I have already mentioned, those of Sir George Richards will be laid before you in The Geographical Journal. Dr. Nansen will no doubt reflect upon what has been said and written, but for the members of the society at large to pronounce any definite opinion upon such keenly-disputed questions as are involved in Dr. Nansen's plans would be out of the question; what we can do is to assure him of our most cordial good wishes and to give him as I now do our warmest thanks for his paper.

The following communications have been received from Admiral Sir George H. Richards and Sir Joseph D. Hooker, who were unable to be present at the meeting :-

I venture to offer a few brief remarks on the paper which has been read by the distinguished Greenland traveller and explorer, Dr. Nansen. Dr. Nansen, in his paper, deals mainly with the currents, known ard unknown, in the Arctic regions, and he appears to trust almost entirely to their influence for the accomplishment of his object in reaching the Pole, or rather in being drifted from a position near to the New Siberian Islands, across the Pole to Greenland, a distance, in a direct line, of about 1400 miles. Now to make myself clear I must give in a few words my views of these currents. I believe that there is a constant outflow (I 
prefer this word to current) from the north in consequence of the displacement of the water from the region of the Pole by the ice-cap which covers it, intensified in its density by the enormous weight of snow accumulated on its surface; this outflow is doubtless more pronounced in the portion of the Arctic Circle between the west end of the Parry Isles and Spitzbergen, where the numerous groups of islands cut it up into narrow straits and passages which form so many ducts for its escape to the south. Over the other portion of the Circle which we know less about, and which embraces a far. larger extent of sea, it is doubtless less pronounced in a southerly direction, and there is no decided current through Bering Strait one way or the other, which is probably owing to the very shallow water (less than 20 fathoms) for a considerable distance on either side of its entrance; Bering Strait is the only outlet on that side of the Pole.

Now this general southerly outflow which I have mentioned is of a very weak character, considered as a current, and every ship which has ever penetrated north has had to do so against it, and has found no difficulty in doing so while there has been sufficiently open water or loose ice to make steam or sail power available; when this has not been the case, and a ship has not got within the inner waters before the new ice of autumn is formed, she is certain to be carried back by this outflow by slow degrees with the ice, and to reach the open water probably early in the spring. I cannot find any reason for believing that a current sets north over the Pole from the New Siberian Islands which Dr. Nansen hopes for and believes in. Dr. Nansen, I think, calculates it at about 2 miles a day; there is nothing in the Jeannette expedition to support such a theory; she made something like 900 miles from Bering Strait in nearly two years, in a direction north of west, or nearly with the line of coast, and was then crushed near the position where Dr. Nansen's current commences.

It is my opinion that when really within what may be called the inner circle, say about $78^{\circ}$ of latitude, there is little current of any kind that would influence a ship in the close ice that must be expected; it is when we get outside this circle, round the corners as it were, into the straight wide channels, where the ice is loose, that we are really affected by its influence, and here the ice gets naturally thinner and more decayed in autumn, and less dangerous to a ship. Within the inner circle probably not much of the ice escapes; it becomes older and heavier every year, and in all probability blocks the navigation of ships entirely. This is the kind of ice which was brought to Nares' winter quarters at the head of Smith Sound, in about $82^{\circ} 30^{\prime}$ north, and this is the ice which Markham struggled against in his sledge journey, and against which no human power could prevail.

I must not omit to allude very briefly to the only tangible evidence which Dr. Nansen brings in support of his currents, viz., the articles said to have been found in Greenland belonging to the Jeannette. I don't for a moment impute any bad faith to the authors of this story, nor do I include it among the many fables which have been rife since the Franklin Expedition, most of them made to order as marketable articles, but I attach no real importance to it. If found in Greenland they may well have drifted down on a floe from the neighbourbood of Smith Sound, from some of the American Expeditions which went to Greely's rescue. It may also well be that some of "De Long's" printed or written documents, in regard to his equipment, may have been taken out by these Expeditions, and the same may apply to the other articles. But even if it were possible to accept this evidence it would only mean that a piece of ice with these relics bad been coach-wheeled in some way round the polar basin to Greenland in three years, and could not afford a very encouraging hope for Dr. Nansen's ship. I regret to have to speak discouragingly of this project, but I think that any one who can speak with authority, ought to speak plainly 
where so much may be at stake. I have always rested my hope of the North Pole or its neighbourhood being reached by sledge journeys along the land ice, north of Smith Sound. The expedition of 1875, however, under Nares dissipated this hope by proving the improbability of any land at a convenient distance in that direction, and if this is so, there remains only the possibility of its accomplishment by ship navigation. I confess that I have never been an advocate of amateur nautical expeditions for such service as this ; and for obvious reasons. It must be admitted, however, that they have one advantage; their anxieties are not added to by the knowledge that they become the objects of rescue almost before they are well into the regions of danger.

In Government Expeditions, especially from this country, the excessive caution which it is perhaps necessary to insist on to ensure the certainty of a safe retreat, demands a system of supports which fetters the action of the commander, and by separating his ships during winter, deprives him virtually of half his travelling force in early spring. Such reasons will probably be a bar to any Government Arctic enterprise for many years to come; whatever may be undertaken in the Antarctic region, which is virgin ground, and where the conditions are probably so different, that it may not be necessary to pass a winter, at any rate where a reconnaissance would first be made. The solution of the Polar problem, if it is ever solved, may therefore possibly be effected by some such effort as the present one.

All British Arctic men will, I believe, hope that Dr. Nansen may be the successful explorer, and that he may reap the reward due to his pluck and enterprise. They will certainly welcome him home, successful or unsuccessful, long before the expiration of the almost countless years for which he is prepared to persevere. I think he is very wise to commence his voyage by way of the Kara Sea, instead of by Bering Strait, to reach which and get on the threshold of his labours a voyage of about 20,000 miles must first be accomplished. By adopting Nordenskiold's course he is certain at any rate to add something to our knowledge of these littleknown regions.-George HeNry Richards.

In compliance with your request, I have carefully studied Dr. Nansen's able and clear statement of his reasons for adopting the course he has chosen for reaching the hitherto unexplored Arctic area, and his preparations for its accomplishment.

Dr. Nansen's project is a wide departure from any hitherto put in practice for the purpose of Polar discovery, and it demands the closest scrutiny, both on this account and because it is one involving the greatest peril. The following considerations respecting it have occurred to me.

From my experience of three seasons in the Antarctic regions I do not think that a ship, of whatever build, could long resist destruction if committed to the movements of the pack in the Polar regions. One built as strongly as the Fram would no doubt resist great pressures in the open pack, but not any pressure or repeated pressures, and still less the thrust of the pack if driven with or by it against land. The "lines" of the Fram might be of service so long as she was on an even keel, or in ice of no great height above the water-line, but amongst floes and bergs, or when thrown on her beam-ends, they would avail her nothing.

The contingency of the Fram being, by a divergence of the assumed currents, stranded on the north coast of Greenland, or of the American Polar Islands, or elsewhere, should be taken into account. Assuming that a landing could be effected, it must be on an inhospitable and probably ice-bound coast, or on the mountainous ice of a palæocrystic sea. With a certainly enfeebled, and probably 
reduced ship's company, there could, in such a case, be no prospect of reaching succour.

Putting aside the possibility of scurvy (against which there is no certain prophylactic), have the depressing influences on the minds of the crew, resulting from long confinement in very close quarters during many months of darkness, extreme cold, inaction, ennui, constant peril, and the haunting uncertainty as to the future, been sufficiently taken into account? Perfunctory duties and occupations do not avert the effects of these conditions; they hardly mitigate them, and have been known to aggravate them.

I do not consider the attainment of Dr. Nansen's object by the means at his disposal to be impossible; but I do consider that the success of such an enterprise would not justify the exposure of valuable lives for its attainment; and I may conclude with expressing the hope that Dr. Nansen may dispose of his admirable courage, skill, and resources in the prosecution of some less perilous attempts to solve the mystery of the Arctic Area.-Jos. D. Hooker.

\section{EXPLORATION AND CHARACTER OF THE PRINCIPAL NEW ZEALAND GLACIERS.*}

By A. P. HARPER, Hon. Sec. New Zealand Alpine Society.

THE broad features of the mountain system of the South Island of New Zealand are tolerably well known, and need only be briefly referred to here. Beginning at the north end of the South Island, we find, in Nelson and Marlborough Provinces, numerous ranges spreading from coast to coast, and reaching in many instances tol over 8000 feet. They include some grand peaks, on which snow is to be seen during most of the year, while the lower spurs are clothed in luxuriant forest, of which a considerable area has been "cleared" and brought under cultivation. Further south these ranges draw together, till, in the Southern Alps, they form a great mountain wall, running from N.E. to S.W., which sends off a number of spurs rising into bold Alpine peaks, and for upwards of 100 miles presents a snowy barrier, crossed last season for the first time, by a pass lying at the head of the Godley Glacier, in the north-east of the district embraced by the map.

To the eastward the Southern Alps send out great buttresses, terminating suddenly in the broad Canterbury and Mackenzie plains, which form, by their absolute flatness, a striking contrast to the peaks behind; while westward the mountains slope rapidly, and in many cases fall in sheer precipices for some thousands of feet to the coast, leaving about 10 miles of comparatively level country between them and the sea.

To the south, in Otago, we find the chain spreading out again from coast to coast in lower hills, amongst which are flourishing farms and

* Map, p. 96. 